\author{
Aneta Jankowska \\ University of Gdańsk \\ a.j2@wp.pl
}

\title{
The profession of medical practitioners vs aesthetic medicine and dermatology treatment practice
}

\begin{abstract}
The objective of the article is to reflect of the absence of separation of aesthetic medicine procedures from the total regulations applicable to exercising the profession of medical practitioners. Doubts may arise as to whether a medical practitioner performing procedures not directly focused on the achievement of a therapeutic goal, provides health services within the meaning of the Act of medical activity. ${ }^{1}$ It is also worth thinking about whether in the legal system of health protection there truly is no consistent differentiation between procedures directed at achieving a therapeutic goal and those not directed at this goal. Hence, one may ask whether the well-established ethical principles of the profession of medical and dental practitioners provide for a possibility to provide services other than therapeutic ones. Moreover, it is worth noting that in order to provide services within a given field crucial in the profession of a medical or dental practitioner, doctors should acquire theoretical and practical skills developed over years.
\end{abstract}

Key words:

aesthetic medicine, medical practices, ethical principles, health care services, medical ethics

\section{Introduction}

The 21st century is the time when the youth cult thrives. Currently, appearance plays a crucial role in interhuman relations and is a frequent marker of one's professional, social and financial position. That is because the effects of aesthetic medicine procedures most often comprise changes in appearance, i.e. correcting or improving it. Many people decide to undergo an aesthetic medicine treatment to feel comfortable in their bodies or to correct some beauty defects. The most popular procedures are beauty and dermatology treatments, plastic surgeries, plastic gynecology treatments, and the broadly understood aesthetic dental medicine - prosthetics. An extensive array of aesthetic medicine surgeries allows many to take advantage of its achievements at any age. Nonetheless, the specificity of various aesthetic medicine procedures requires a holistic approach to all activities by experienced and adequately trained medical staff, taking account of the needs of the skin and bodily or beauty defects of the patient. In today's reality, aesthetic medicine procedures are being more commonly introduced in dental

1 Act on medical activity of 15 April 2011, Dz. U. (Journal of Laws) of 2011 no. 112 item 654. 
or other individual medical practices. However, they are often unsuited to the performance of the above specified services, which would be directly focused on achieving a therapeutic goal.

\section{The aim of medical activities}

Without a doubt, attention should be paid to the fact that the goal of medical activities ${ }^{2}$ in medical practice has recently changed its course. The aim becomes more and more often different from the one long-established by the legal and ethical principles of the medical profession. Nowadays, it may occasionally fail to fall within the regulatory framework of health care activities or medical competencies. It sometimes goes beyond the generally adopted ethical principles. It surpasses disease treatment, lifesaving and health care services provision. Instead, it focuses on addressing expectations related to patients' appearance and their dreams about an ideal look. It may occur that it even surpasses the medical field in which a given medical practitioner specializes and should practice according to the acquired qualifications. It is caused by patients' ever greater interest in such services.

It is common knowledge that there are no normative acts (prescriptive instruments) which would regulate powers necessary to perform aesthetic medicine procedures in the currently binding legal status. Upon graduation, medical or dental practitioners who start to provide aesthetic medicine services hold qualifications allowing them, only, to break down the continuity of the skin. Another important issue is the fact that the nursing profession, which is a part of medical staff, also holds such powers. However, any such procedure may not be treated as performed legally if conducted by a medical professional, should the operator not have other specific skills. Moreover, if the medical community performs aesthetic medicine treatments without a health care goal, this does not constitute provision of medical services. Therefore, to have an opportunity to perform the above described services, the professional group of medical practitioners should deepen their medical knowledge in the field of aesthetic medicine at targeted postgraduate programs and be equipped with skills and many years of practical experience, which would reduce the risk of potential postoperative complications.

\section{Differences between the terms "aesthetic medicine" and "health care service"}

To permit a reasonable understanding of the substance of the subject matter, two terms should be defined: "aesthetic medicine" and "health care service" provided by a medical practitioner. The term "aesthetic medicine" has no single commonly binding definition in

2 "The goal of medical activities is assumed to involve the goal to eliminate any health issues" - a deeper insight into the topic: M. Boratyńska, Indywidualne preferencje pacjenta a celowość leczenia, in: System Prawa Medycznego. Regulacja prawna czynności medycznych, E. Zielińska (ed.), Vol. II, part 2, Warsaw 2019, p. 841; More on the subject: M. Boratyńska, P. Konieczniak, Zasady Prawa Medycznego. Podstawy i przesłanki legalności czynności medycznych, in: System Prawa Medycznego..., p. 97. 
the legal thought and, as already mentioned, there are no concrete legal regulations pertaining to it. The term aesthetics derives from the Greek word aisthesis which means a sensation or love of beauty. In medicine, it may be defined as an action aimed at supporting beauty preservation, preventing loss of beautiful appearance, or slowing down individual aging processes. Aesthetic medicine is a field which focuses on appearance, image and aesthetics and, according to various literary sources, it originated in France where the term la médecine de l'amélioration, i.e. ameliorating medicine, was coined. ${ }^{3}$ As early as in the ancient times, people started to carry out procedures aimed at appearance changing. One example is ancient China, where young girls' feet used to be deformed to make them smaller. ${ }^{4}$ Attempts to remove natural flaws or flaws resulting from accidents were undertaken in the 18th century B.C. in ancient Egypt, too. ${ }^{5}$ Poland, in turn, witnessed the arrival of aesthetic medicine in the early 1990 s.

In turn, the term "health care service" appears in many legal acts relating to the pursuit of the activities of medical and dental practitioners. Among others, it may be found in the Act on the profession of medical and dental practitioners ${ }^{6}$ and in the Act on health care services financed with public funds. ${ }^{7}$ What is more, it is applied in the Act on patient rights and patient ombudsman and in the Act on medical activity. In all of the above specified acts, a "health care service" is defined and understood as an activity aimed at health saving, maintenance, recovery, or improvement of one's health and other medical activities resulting from the treatment process, or separate provisions regulating the principles of their performance. ${ }^{8}$ All of the above listed elements point to a therapeutic goal, which includes prevention, diagnostics, medical rehabilitation, and the issuance of medical statements and opinions. ${ }^{9}$ It is also called a medical treatment, directed at remediation of a health problem of a patient, focused on protecting patient's life or health, and performed in accordance with one's medical knowledge and by a qualified personnel. ${ }^{10}$

As already mentioned, this medical field has not been legally regulated as a medical specialization - aesthetic medicine continues to be an area of medicine, nothing more. It is situated somewhere between dermatology and plastic surgery. When analyzing the above quoted definition of a health care service, we shall highlight that activities aimed at health preservation mainly focus on carrying out preventive actions which are to prevent the formation of various diseases. Protecting or saving one's health involves the use of methods which are to stop or decelerate disease processes affecting one's body. Next, recovery encompasses ensuring that the patient is safe and has good conditions to regain health. Finally, health improvement may boil down to a state in which the patient has not

3 D. Folschied., J.J. Wunenburger, La médecine de l'amélioration, in: D. Folschied, B. Feuillet-Le Mintier., J.F. Mattei, Philosophie, éthique et droit de la médecine, Paris 1997, pp. 221-232.

$4 \quad$ R. Kubiak, Czynności kosmetyczne (estetyczne), in: System Prawa Medycznego..., p. 779.

5 R. Kubiak, Prawo Medyczne, Warsaw 2010, p. 635.

6 The Act on the profession of medical and dental practitioners of 5 December 1996, Dz. U. (Journal of Laws) of 1997 no. 28 item 152.

7 The Act of 27 June 2004 on health care services financed with public funds, Dz. U. (Journal of Laws) of 2004 no. 210 item 2135.

8 The Act on medical activity, consolidated text Dz. U. (Journal of Laws of 2018) item 2190 as amended.

9 R. Kubiak, Prawo Medyczne, op. cit, p. 19.

10 Ibidem. 
been before. ${ }^{11}$ Therefore one needs to conclude that medical or dental practitioners carrying out a procedure without a justified medical reason are not providing health care services. Professional activities carried out by a doctor ought to be performed in accordance with recommendations of medical knowledge, as determined in Article 4 of the Act on the profession of medical and dental practitioners. Similarly, Article 57(1) sentence one of the Code of Medical Ethics indicates that "Medical practitioners may not use methods found by science to be harmful, worthless or not scientifically verified". ${ }^{12}$ This is why aesthetic medicine procedures should be performed if need to by medical practitioners who have completed post-graduate studies the field of which should cover dermatology, surgery as well as broadly understood cosmetology.

Another key issue in the provision of health care services is the taking of patient's medical history and making sure that the patient (client, consumer) who is the object of a given cosmetic procedure has not overlooked anything while reporting his health status. An aesthetic procedure, as any medical procedure involves interference with the human body. It carries a risk of potential complications, which can influence the overall health condition. One of the risks include necrosis or embolism following an injection of a substance into a blood vessel. In worst case scenarios, a procedure may lead to an anaphylactic shock. ${ }^{13}$ The risk attendant to the performance of the profession of medical or dental practitioners means all types of danger patients are exposed to due to their involvement with a diagnostic, treatment or even disease prevention processes. ${ }^{14}$ Risk assessment encompasses not only the type of performed medical activity, but also the general health condition of a patient, the conditions surrounding a given medical activity and, finally, the experience and competence of a medical or dental practitioner.

\section{Ethical principles governing the medical profession}

Two fundamental principles of doctors' morality, primum non nocere (first, do no harm) and, salus aegroti suprema lex esto (the health of the patient should be the supreme law), should be applied simultaneously, for the former indicates the intention of one's professional actions and the latter determines the limitations resultant from their implementation. ${ }^{15}$ Any interference in a human body entails some risk. Aesthetic medicine procedures may also have negative consequences whenever an intervention in a human body fails. The question is whether a doctor has the right to undertake risky non-medicinal actions and what principles should be followed? The answer to the above question is the so-called proportionality rule described by T. Brzeziński, which assumes that "every medical activity must be justified by an underlying goal which is to be attained and should not be a greater risk for the patient than the risk we wish to remove therewith". ${ }^{16}$

11 M. Boratyńska, P. Konieczniak, Zasady Prawa Medycznego..., pp. 94-95.

12 Kodeks Etyki Lekarskiej, Warsaw 2004, p. 27.

13 A. Markowicz, Powikłania po zabiegach estetycznych, "Aesthetic Business", 2019, no. 5, Poznań 2019, pp. $104-105$.

14 T. Brzeziński, Etyka Lekarska, Warsaw 2011, p. 131.

15 M. Boratyńska, P. Konieczniak, Zasady Prawa Medycznego..., p. 41.

16 T. Brzeziński, op. cit., p. 131. 
Article 2(2) of the Medical Ethics Code provides that "the vocation of every doctor is to protect human life and health, prevent diseases, treat the sick, and relieve human suffering. What is more, a doctor may not use medical knowledge and skills in actions contrary to this vocation". ${ }^{17}$ Therefore, one may ask whether, in accordance with the Medical Ethics Code, a doctor having a duty to provide the above listed health care services is also empowered to perform other actions, such as cosmetic activities, within the limit of breaking the continuity of human tissue. Are the procedures the aim of which is solely to improve one's physical appearance of a therapeutic or medicinal nature? Are they justified in the performance of a medical profession from the ethical point of view?

In literature, it is frequently emphasized that cosmetic or beauty treatments may be either conducted for medical purposes or, due to a common need to have a different, better, prettier look, oriented at aesthetics or image improvement. Many a time, it appears that cosmetic or aesthetic procedures are deemed to have a medical goal, for instance in cases when they are related to one's mental condition resultant from congenital defects, accidents, diseases, or consequences of treatment. Such situations may often result in developing neuroses or personality disturbances. In such cases, the legislator included cosmetic, aesthetic procedures as part of the guaranteed services of inpatient health care, which comprise, among others, the procedures of plastic surgery, ${ }^{18}$ which is a medical specialty. It is essential that any medical activity should be carried out by a competent and qualified person due to the requirement of adequate knowledge and experience in a given medical procedure. Additionally, any such procedure ought to be performed upon informed consent of the patient or other authorised persons.

According to source literature, when analyzing the above quoted Article 2(2) of the Code, disease prevention is medical activity involving popularizing preventive actions targeted at patient hygiene, following a healthy diet, promoting physical activity, and counteracting smoking, alcohol abuse or use of drugs. It boils down to medical practitioners' directing patients to conduct healthy and suitable lifestyles. ${ }^{19}$ Treating patients is a holistic process that starts with a diagnosis and ends with a therapeutic or rehabilitation process. Alleviating one's suffering or providing relief refer to both physical and mental human suffering that may be diminished by the application of treatment methods or pharmaceuticals that are capable of soothing pain, or by showing empathy and compassion for another man.

Ethics has always been associated with morality and it discusses human lives captured in individual and social norms. It is related to human action created by the man himself. At the same time, it affects other people's actions, oftentimes becoming results or consequences for some others. Moral norms, however, determine what is good and bad, and why, in a given professional or social environment. ${ }^{20}$ Every human being takes his actions into his own hands according to his own conscience; he should reflect, though, on the moral values which ought to accompany his daily professional duties. Such a reflection constitutes an effort because it makes one realize that he serves some purpose. Generally, etiquette focuses

17 Kodeks Etyki Lekarskiej, op. cit.

18 R. Kubiak, Prawo Medyczne, op. cit., p. 638.

19 K. Linke, Komentarz do art. 1-5 Kodeksu Etyki Lekarskiej, "Medyczna Wokanda” 2015, no. 7, p. 16.

20 K. Wojtyła, Elementarz etyczny, Lublin 1983, pp. 19-21. 
on honor and dignity and every ethical decision made by a doctor that should concentrate on protecting a patient's health is also a moral decision which ought to be closely associated with moral values. ${ }^{21}$

\section{Substantiation of the objective of undertaken medical activities}

Unfortunately, nowadays, activities undertaken by physicians oftentimes go beyond the above specified ethical principles and are performed for aesthetic purposes in the absence of medical grounds. They are performed by doctors of various specializations and also non-specialist physicians. They do not have sufficient knowledge of dermatology or surgery, or experience. To classify aesthetic medicine procedures as therapeutic actions, one would need to undertake them for therapeutic or medicinal purposes, which consists in a thesis that they should be aimed at lifesaving, health-protection or at alleviation of physical or mental pain. ${ }^{22}$ Therefore, here we can pose another question: do non-therapeutic actions, which cover aesthetic medicine procedures, fall within the category of redundancy? As Maria Boratyńska notes, „redundancy means inexplicability of undertaken actions, which signifies absence of healthcare needs in a patient of a given clinical status". ${ }^{23}$ The said redundancy may frequently be affected by the patient's will expressed by an individual need to alter one's appearance or to enhance one's beauty, not necessarily being in accordance with the therapeutic goal. Nonetheless, no indications to perform a procedure in such cases from a clearly medical point of view - i.e. to save or protect life - disqualifies it in a clearly medical category. Such measures presume that there is a certain subjective appraisal.

The extremely crucial aspect of implementing doctors' actions is the suitability of the performance of any procedures involving human body interventions and the risks they carry. Oftentimes, non-medical procedures concerning beauty enhancement are done because the patient insists on or talks the doctor into it. It requires one to take account of the situation, social and other, of the patient who does not feel well or comfortable in his own body. A patient insisting on the performance of a procedure is tantamount to the patient's informed consent to the breaking of bodily continuity due to, among other things, her wish to have a better, prettier look. In such a case the medical practitioner should take into consideration the patient's needs. It should be a doctor with adequate qualifications, knowledge and experience. Nonetheless, it is unjustified to interfere with a human body without any therapeutic goal by a person without adequate education. If an activity has no medical justification it is at the same time illegal and entails liability.

As the legal basis in the reflection on superfluity (redundancy) or legitimacy of performing medical activities, we must quote the regulation of Article 4 of the Act on the profession of medical and dental practitioners, which provides that "A doctor shall perform his profession in accordance with indications of the current medical knowledge, using available methods and means of prevention, diagnosis and treatment of diseases, following the principles of pro-

21 M. Boratyńska, Indywidualne preferencje pacjenta..., p. 841.

22 R. Kubiak, Czynności kosmetyczne..., p. 791.

23 M. Boratyńska, Indywidualne preferencje pacjenta..., p. 825. 
fessional ethics and with due diligence". ${ }^{24}$ This duty is reflected in the patient's right stipulated in Article 6(1) and (8) of the Act on the Rights of the Patient and the Patients Ombudsman, ${ }^{25}$ hence the performance of an activity that is redundant and preconditioned by a lack of medical justification is incompatible with adopted legal and ethical principles typical of the profession of medical and dental practitioners. Therefore, in the case of taking up therapeutic methods and actions not based on scientific evidence and, as such, infringement of patient's rights to health care services corresponding to the current medical knowledge, the patient has the right to file a claim against the doctor at any time.

Prior to the performance of any medical service, an informed consent must be obtained from a patient or another entity authorized to grant it. Obtaining the informed consent of a patient before the provision of medical services constitutes an assurance of the legal capacity of the patient and is one of his most vital rights. ${ }^{26}$ Such a consent should be preceded by the provision of information regarding the aim, need, and method of the procedure, as well as potential complications. As is clear from, among others, Article 31(1) of the Act on the Profession of Medical and Dental Practitioners, the content of which is as follows: "A doctor shall inform the patient or his statutory representative in an intelligible manner about his health condition, diagnosis, suggested and practicable diagnostic and treatment methods, foreseeable consequences of their application or renunciation, treatment outcomes and prognosis" ${ }^{27}$ Such information should be communicated in a detailed and reliable fashion and shall account for all aspects that might affect the decision made by the patient. ${ }^{28}$ The informed consent of the patient is one of the basic conditions of the legitimacy of medical procedures and the provision of any medical service.

In the examination of the field of aesthetic medicine, it must be concluded that to a large extent the patients of medical or dental practitioners providing aesthetic services are healthy individuals unaffected by medical conditions, who wish either to improve their looks or to withhold the natural aging processes. Therefore, persons enjoying such services should not be referred to as patients. A more appropriate term here would be consumers or clients, for aesthetic medicine procedures are non-curative, non-therapeutic, non-health-oriented procedures. The "patient", within the wording of the Act on the Rights of the Patient and the Patients Ombudsman is "a person who requests the provision of health care services or using health care services provided by an entity which provides such services or a person pursuing a medical profession". ${ }^{29}$ Given the above definition, saying that "someone is a patient" has been correlated with the provision of a health care service or with awaiting its provision. ${ }^{30}$

24 Act of 5 December 1996, Dz. U. (Journal of Laws) of 1997 no. 28 item 152.

25 The Act of 6 November 2008 on Patient's Rights and the Patients Ombudsman, Dz. U. (Journal of Laws) of 2009 no. 52 item 417.

26 R. Kędziora, Odpowiedzialność karna lekarza w związku z wykonywaniem czynności medycznych, Warsaw 2009, p. 73 .

27 Act of 5 December 1996, Dz. U. (Journal of Laws) of 1997 no. 28 item 152, 114

28 T. Brzeziński, op. cit., p. 105.

29 Act of 6 November 2008 on Patient's Rights... and the Patients Ombudsman, item 417.

30 P. Konieczniak, Prawa pacjenta, in: System Prawa Medycznego..., p. 341. 


\section{Conclusion}

The therapeutic goal always focuses on solving health issues, both physical and mental. Health issues relate to good health and sickness, whereas a medical goal is understood as an intention to "serve good health" or "fight disease". ${ }^{31}$ Every decision made by a physician and involving interference in human body is a moral decision, while a medical or dental professional should be able to see what is most important when taking a decision: the facts or values. It is this valuation that requires one to take a position on what is more important: the patient's wishes or medical reasons? Undeniably, the needs of a person turning for help to a medical professional are very important. A physician should provide help to any person in needs. However, the aim of his medical activities should be directed utterly at the patient's good and safety. Comprehensive knowledge of general medicine, dermatology, surgery and broadly understood cosmetology is necessary in order to perform any type of aesthetic medicine procedures. A person who does not have those should not undertake to perform such procedures. Not only is it unethical from the point of view of pursuing a medical or dental profession, but also dangerous to the patient and at the same time to the person performing these procedures, given the risk of criminal, civil or professional liability.

\section{Literature}

Boratyńska M., Indywidualne preferencje pacjenta a celowość leczenia, in: System Prawa Medycznego. Regulacja prawna czynności medycznych, E. Zielińska (ed.), Vol. II, part 2, Warsaw 2019.

Boratyńska M., Konieczniak P., Zasady prawa. Podstawy i przesłanki legalności czynności medycznych, in: System Prawa Medycznego. Regulacja prawna czynności medycznych, E. Zielińska (ed.), Vol. II, part 1, Warsaw 2019.

Brzeziński T., Etyka lekarska, Warsaw 2011.

Folschied D., Wunenburger J.J., La médecine de l'amélioration, in: Do. Folschied, B. FeuilletLe Mintier, J.-F. Mattei, Philosophie, éthique et droit de médecine, Paris 1997.

Kędziora R., Odpowiedzialność karna lekarza w związku z wykonywaniem czynności medycznych, Warsaw 2009.

Konieczniak P., Prawa pacjenta, in: System Prawa Medycznego. Regulacja prawna czynności medycznych, E. Zielińska (ed.), Vol. II, part 1, Warsaw 2019.

Kodeks Etyki Lekarskiej, Warsaw 2004.

Kubiak R., Prawo medyczne, Warsaw 2010.

Kubiak R., Czynności kosmetyczne (estetyczne), in: System Prawa Medycznego. Regulacja prawna czynności medycznych, E. Zielińska (ed.), Vol. II, part 2, Warsaw 2019.

Linke K., Komentarz do art. 1-5 Kodeksu Etyki Lekarskiej, “Medyczna Wokanda” 2015, no. 7.

31 M. Boratyńska, P. Konieczniak, Zasady Prawa Medycznego..., pp. 106-107. 
Markowicz A., Powikłania po zabiegach estetycznych, in: “Aesthetic Business” 2019, no. 5, Poznań 2019..

Wojtyła K., Elementarz etyczny, Lublin 1983.

\section{Legislative acts}

Act of 5 December 1996 on the profession of medical and dental practitioners, Dz. U. (Journal of Laws) of 1997 no. 28 item 152.

Act 27 June 2004 on health care services financed with public funds, consolidated text, Dz. U. (Journal of Laws) of 2004 no. 210 item 2135.

Act of 15 April 2011 on medical activity, Dz. U. (Journal of Laws) of 2011 no. 112 item 654.

Act of 6 November 2008 on Patient's Rights and the Patients Ombudsman, Dz. U. (Journal of Laws) of 2009 no. 52 item 417. 